\title{
Being-understanding as the basis for the possibility of human essence in the modern environment
}

\author{
Tatyana Torubarova ${ }^{1, *}$ and Olga Dyachenko ${ }^{1}$ \\ ${ }^{1}$ Kursk State University, 29 Radishcheva St., Kursk, 305000, Russia
}

\begin{abstract}
The article analyzes the understanding of being in the metaphysical experience of man. It is shown that having in us beingunderstanding is a fundamental experience in comprehension of the possibility of human essence, for it turns us to the origins of the rootedness of man in his own foundational content. It is argued that the understanding of being and the question of the essence of time constitute together the questioning about man, about the basis of his essence. In this respect the specificity of comprehension of man as a being present in the world is revealed. The position of human existence in the contemporary world is revealed, where the humanitas of man, that is being fulfilled, deprives him of any essence. The being of all things existent is understood as nothingness that man has to fill up with his knowledge, and the unity of human essence with the being of all things existent is rejected. This actualizes and makes urgent the targeted problem.
\end{abstract}

\section{Introduction}

Consideration of the problem of understanding of being in the metaphysical experience of man always reverses us to comprehension of man's essence, his relation to the world and to all things existent. With all the variety of works devoted to the study of man, of human nature in various branches of scientific knowledge, we have to admit that most of them, and above all philosophical studies, focus only on some particular aspects of the human essence. For example, Juan Andrés Mercado of the Pontifical University of the Holy Cross has focused on the problem of harmonization of different human faculties as an important characteristic of human essence [1]. A team of researchers from Romania (A. Munteanu, I. Costea, R. Palos, A. Jinaru) seeks to comprehend the essence of human personality, turning to the empirical study of archetypes [2]. In this connection there is an interesting point of view of the English researcher Anne Phillips who, analyzing different points of view concerning the question of equality, the rights and freedoms of the individual, speaks about uncertainty of human nature [3]. A similar position is held by Chinese scholars Kun Wu, Kaiyan Da, who deny the existence of "absolute, fixed essence" [4]. Among the Russian scientists who analyze the problem of being, the works of G.V. Baranov [5] should be mentioned. However, he comprehends being to a greater extent in the context of ontology. In the study of human

\footnotetext{
*Corresponding author: ttorubarova@,rambler.ru
} 
essence, he dwells only on the analysis of those trends that have developed in the mainstream of philosophical knowledge [6]. The problem of things existent and essence is dealt with by M. Gusev [7], and also by A. M. Gaginsky who examines in detail the meaning of being and the meaning of things existent [8]. N.A. Tereshchenko and T.M. Shatunova propose to consider the essence of man and his way of being in the world through the "concept of the social" [9].

Thus, being-understanding as the basis for the possibility of human essence has not been the subject of specific research.

The aim of the study is to explicate the metaphysical context of understanding of being as a key and fundamental experience of comprehending the human essence.

\section{Materials and methods}

The methodological basis of this study is the method of ascent from the abstract to the concrete, which allows us to reveal the problem of the metaphysical foundations of man's being. The methods of structural and functional analysis were used to comprehend time and temporality in the context of understanding man's being. The application of the systemic approach allowed to consider the peculiarities of the constitution of existentia and essentia concepts which have been used to define being since the Middle Ages and which received their explication in new European philosophy.

\section{Relevance}

Being as a theme of philosophical reflection has gained the right to be with the beginning of philosophy itself. Whenever we think about the most essential things, we inevitably discover the existence of being-understanding in us. However, this understanding does not necessarily include any of the essential characteristics of being itself. It is clear that being as such is as indistinguishable as matter itself, but it is still somehow articulated in our understanding. Of course, understanding being is not the same as understanding and recognizing this or that thing, since being and any things existent are not one and the same. If we ignore the implicit or explicit understanding of being, then it is impossible to put forward a question of being at all. We find a way to comprehend the problem of being if we find out the following: which understanding of being appears to be predominant in a particular period of history. Even if we consider this understanding only in a generalized and purely tentative manner, even in this examination we are confronted with the basic and dominant human attitude towards all things existent and the world as a whole. It is not a question of some characteristics of the human being. It is about something more or less definite in man, namely his inherent understanding of being. This kind of understanding has in many and essential respects an a priori nature. It is not just a random feature of the human being along with his many other features. No, it is much more important than that. This understanding permeates man's relation to all things existent, including his relation to himself. The understanding of being, or being-understanding, which cannot be reduced to ontology, not only permeates the whole relation of man to all things existent, as if it were always present and present in advance. Such an understanding is the very condition of the possibility of man's relation to all things existent and to things existent in general. If man did not have this understanding, he would not be able to relate to himself as to a thing existent, already by virtue of the transience of his earthly life. Then he could never be himself, could not say "I" and "you" about himself, could not be a personality. Man himself would be impossible in his essence. Thus, beingunderstanding is the basis for the possibility of the very essence of man. 


\section{Discussion}

If we ask about being and find out the prevailing understanding of being at a given time, we are inevitably moved to ask about man himself. The question about the basis of human essence thus becomes simply unavoidable. The question of being thereby refers us to the origins and rootedness of the human being as such in his own foundational content.

But the question of time belongs to the question of being and to the problem of understanding being. If the question of time forms the problematic basis of the question of being, then we no longer have the choice of asking or not asking at our own discretion about time, about the mutual belonging of man and time. We have to ask about time, because time is precisely the basis of the possibility of understanding being, and thereby also the possibility of human essence foundation. Then time is first of all what is present in man. I. Kant, in fact, is forced to comprehend the essence of time in this way. The question about understanding being and the question about the essence of time constitute together the questioning about man, about the basis of his essence. This kind of questioning exceeds the sphere of all that is taken into account and considered in the ordinary questioning of man about himself. When in our questioning the possibility of understanding being in time is revealed to us, then we sooner or later discover that precisely in the entire breadth of being-understanding man is able to construct himself in relation to all things existent as a whole. When the very possibility of such understanding is removed, then man loses his basis, and therefore he can no longer act from the foundation of his essence; then the connection of times is destroyed and man loses his own time.

What is understanding being? Understanding being implies its definiteness. "Understanding" means the same thing as clarifying how being becomes perceptible. If we define being in the mode of understanding it, then man's being is understood as that which understands itself in its being. However, what is meant here is not simply subjectivity. In defining man's being as subjectivity, it is not the existence of consciousness at all that is key, but rather his self-consciousness becomes his fundamental characteristic. Self-consciousness is not merely a concomitant mode of consciousness self-expression. It constitutes in itself the possibility of comprehending what man is, and in fact, is the constitutive essence of consciousness in the context of man's comprehension of himself. Understanding being first refers to being, which is man's being. This refers to something other than consciousness itself because self-consciousness is understood existentially, that is, as a representation of the self as a thing in existence. Existence is that which is apprehended in being itself. Being then implies such existential thing existent which the human being is. But what is this being in which being understands itself? Man's being is being in the world. He really lives in the world, being present in it as a temporary being. Being in the world is the basic principle and thus that which constitutes the essence of being, being the basis of its inner possibility whether it is true or not. Human presence in the world is only one side of the issue. Since it is being in the world, therefore, man's being is limited in one way or another by presence. But presence in the world does not mean presence in the diversity of things existent called the world.

So what does it mean for a person to be in the world, as being in the world? Understanding being does not only presuppose man understanding himself in his own being or the being of all other things existent; understanding being is a condition of his relation to things existent, and to himself. Man is present not as being here and now, but as M. Heidegger says, being thrown into the open world. The openness of things precisely is called the world. Thus, it is necessary to understand the essence of the world as an opening of being, as R.A. Burkhanov and O.V. Nikulina point out, as "the way the world is revealed to man, what man has found 
in it for himself" [10, p. 13]. Man, then, can be cognized as an entity present within this world. His being is defined "here" and "now" as being in the world. Being in the world is not equal to existing within the world. It is the distinctness of being of man dwelling here and now. Existence refers to that man's being which is his subjective beginning. Presence is the characteristic of the present. In this sense the question arises as to how the "definition of time" is to be understood. The present as ever-present is permeated by time. It is the horizon of facticity, of human presence in the world here and now, where we inevitably distinguish between things existent and being.

It is clear that a thought about things existent and a thought being cannot be uttered in the same sense. The difference lies in the fact that we are trying to think. Every thing existent in the structure of our language is subject to some form of articulation that gives it a proper definition. This is what the recognizability of being is based on. Our understanding of being does not refer to some specific features of man, but touches upon something essential in the human itself. This kind of understanding is a priori in nature. The being-understanding is a condition of the very foundation of the human being, of his foundational substantiality. It attests to man's own rootedness. Without being-understanding, man would be impossible in his essence. It is the foundation of the very human essence and the basis of his relation to anything. In this way, man is understood from being. We inevitably find ourselves involved in the question of the basis of human essence. Whereas being and time are correlated in the context of understanding human essence.

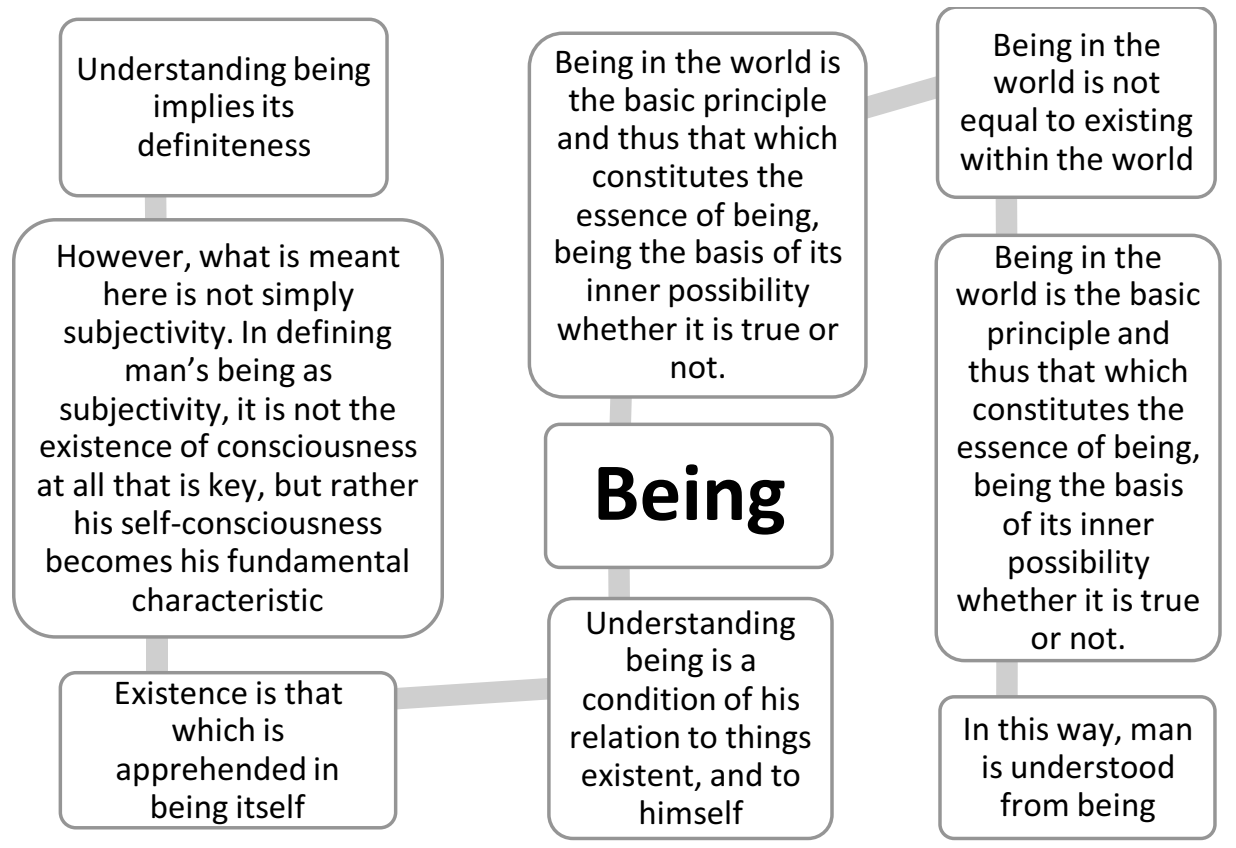

Fig. 1. Understanding of being and its key meanings.

Man, by virtue of his finitude, is a being who exists in time. Temporality constitutes the being-meaning of human being. Understanding being becomes possible only on the basis of time. The question of time constitutes the problematic basis of the question of being. Time is not only the basis for the possibility of understanding being, but also the basis for understanding human essence. We comprehend being from time, i.e. temporally. In doing so, we transcend things existent in order to arrive at being. This transcending excludes any orientation to things existent. The meaning of being is clarified in the horizon of temporality 
which makes the distinction between things existent and being. Each thing existent has its whatness, i.e. its essential definiteness and definite way of being. This raises the question: do these definitions refer to being itself, to the possible articulation of the idea of being? The things existent we are dealing with can be defined by means of a way of being in some way. Consequently, the understanding of being is about the being of things existent, about the way it is. Things existent are the starting point of the consideration of being. It is always defined by the actual experience of things existent, the realm of their possibility. If being is characterized as the understanding of being determined by the actual experience of things existent, then it includes time as its dimension. Up to now, questions about the essence of time have been passed down from generation to generation. For Western European thinking, questions about the essence of time were formulated by Aristotle. Here time is seen as such, according to which something is defined, i.e. measured and counted. The basic essence of time for Aristotle is number, meaning the number used in chronology. As D.A. Fedchuk points out, "Time has its own arche, which ontologically is a foundation of its popular interpretations. The movement in cognition from that which is earlier for our knowledge to that which is earlier by being (as Aristotle thought) is preserved in this case too" [11].

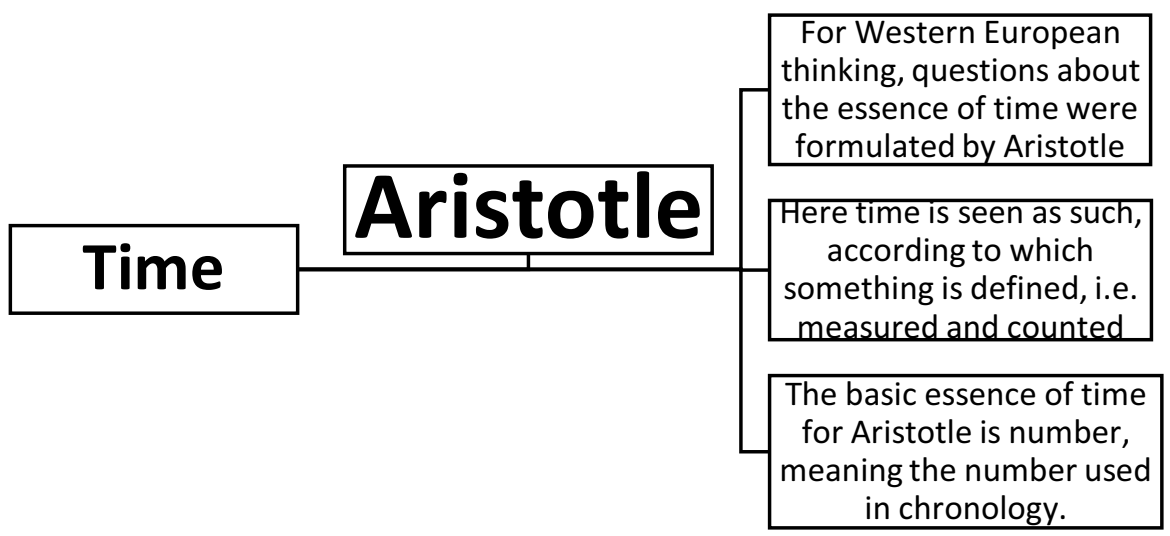

Fig. 2. The origins of understanding time in European philosophy.

If Kant says that time is the pure form of contemplation of inner consciousness, then he is essentially saying the same thing. "Time is only a subjective condition of our (human) contemplation and in itself, outside the subject, is nothingness". Modern researchers often refer to this thought of I. Kant, such as T. S. Kruglikov [12]. Time is a measurement, a form of arrangement of the measurable, an ordering measurement of all things existent. Hence, time is something that exists along with space, motion, materiality of things. The essence of time that has existed till now is presented as that in which all things existent proceed and that according to which all lasting and dwelling is measured, even the highest and eternal things existent. However, the awareness of the essence of time makes it possible to understand that since time immemorial, the being of all things existent has been understood through time. By interpreting being as transitory and temporary it is also clear that being, and in it the existence of man himself, have their essence in the manifestation of time. To be, in fact, must relate to time, i.e. to be temporal. Time is verily the truth of being. Time is the fundamental dimension of human existence, the mode of its finite presence. S. Kierkegaard speaks of "temporality" of man. With that, he believes that the dwelling of man as an earthly being is limited in time and this limitedness of time is a precursor of eternity in the Christian understanding of "eternal bliss". Hence the interpretation of the temporality of being takes on an entirely different meaning. The "temporality" of man's being is usually understood as a fact. The very reality and activity of man proceeds and unfolds in time. "Temporality of the here-and-now- 
being creates an "account of time""'. [13]. Thus, the reality of animals, plants, stones and other things is accomplished. Their life proceeds in the existing or only imagined period of time as a measure of duration. This temporality is called "inner temporality". The temporality of being means not only that man knows his own time and his reality is carried out in time, but that he is always "different" in time. Man knows "the clock", uses this instrument of measuring time to determine "his time", has a "time consciousness", therefore he is very different "in time". This internal temporality of man appears indefinitely, but, the same can be said of animals. Animals do without clocks, but after all swallows fly away in September, ants reproduce in March, and the rooster cock-a-doodle-doos not at ten in the evening, but at four in the morning. The question of temporality of being is not at all concerned with whether man is different "in time" as compared to animals or planets, or with his relation to time, which is exhausted by the fact that he, like many other things, exists in time, only in quite a different way. Man is indeed different "in time", because he considers himself as existing in time, knows time as such and imagines it. But why does man know time as time? Because time itself refers to man's being. Time is intrinsic to him not only as a quality, but it defines being "here" and "now", because being in itself has the character of the temporal. The way in which time exists as such determines the way in which man's being is fulfilled. Whereas the manifestation of time stems from a very different meaning of the word being. This manifestation of time does not only happen because man treats time consciously. Man can take time into account because man's being is determined by the manifestation of time. In the same time all things existent proceed. Therefore, it is not correct to think that time in which man lives seems to be different from time in which planets orbit. This time is the same for man and for the planets. But this time in which man, animals and planets last and spend their lives begins in the time manifested as to be here, whose being is the basis of man's being, but on which man has no influence and which man does not fulfill. As M. Heidegger shows, time defines being.

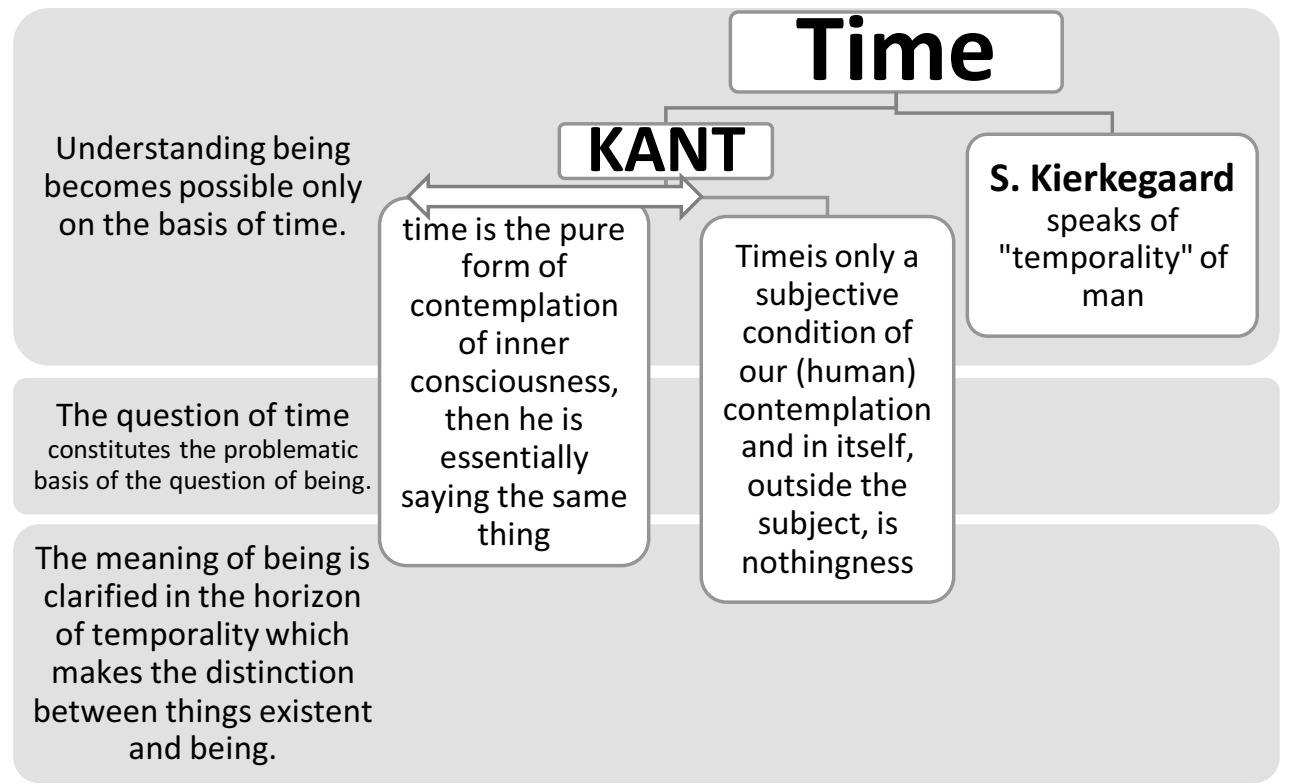

Fig. 3. Time and being.

We are always drawn to that which is whole. And that whole is the world. Then the question arises: what is the world and what are we present in it? We are always present in one way or another in the direction to this whole, we are always on the way to it. We are 
always on the way to this being "as a whole". We are ourselves precisely as such only in this direction. If philosophical comprehension is rooted in a certain kind of being captured, then being captured itself stems from a fundamental orientation. Philosophy thereby engages us into the depths of the human being. And then the question arises: what is man in his essential definiteness? Is he a rational thing existent, but only of a transitional type, is he the return of the divine or, on the contrary, the abuse of all that is divine? We do not know this, but in this enigmatic creature an event called philosophy is taking place. According to the dictum of Novalis, philosophy is nostalgia and in connection with it the longing to be at home everywhere. L.N. Boltovskaya [14] discusses this idea comprehensively in her study. But this aspiration is a transcendence in the entire whole of things existent that are called the world. This is why we wonder what the world is. The world is present only in our being captured by it, and outside of it there is no world as such. In our questioning and searching, in our hesitation, in which we always oscillate between being and nothingness, the finitude of man as such makes itself felt.

The question of being and nothingness, as the most fundamental question, is historical because it reveals the relation of man's being to all things existent, to his unelucidated possibilities and to the future which at the same time connects him to the past, actualizes the past, thus giving it significance in the present. In this kind of questioning our thinking demands history in its full sense, history as the most essential reality of man's being. And the point is not that we get examples or any lessons from history, say, ethical or ideological. We have not yet grasped the historical significance of the questioning of being and nothingness; the very fact that this questioning itself is an integral part of the history of man's being in the world. And in this history, in order to recover the origins of true comprehension of man in his essence, the demand for him by being itself plays a key role. Only then can we truly think and understand man in his essence, in his intrinsically human nature.

Humanism is a reflection on the essence of man's humanity, since inhumanity means being outside one's essence, for man's humanity lies in his essence. According to M.G. Kurbanov, "In philosophical understanding, humanity appears only in man, thanks to whom it acquires wide possibilities of endless variety of the world" [15, p.38]. But from where and then how is the essence of man defined?

In the "Economic and Philosophical Manuscripts of 1844", K. Marx spoke of the necessity of recognizing and revealing the humanity of man, and he found such kind of man's essence in society, in its structure of social and economic relations, which determine the mode of production and reproduction of, first of all, human life. J.J. Rousseau spoke of a "natural" man, but for K. Marx it is a social man. That is, only in society the totality of all human needs is fulfilled, to put it differently, only in society the fulfillment of human nature is guaranteed, "the return of man to himself as a social man, that is, a human man" [16, p. 463]. Christianity saw humanitas homo as opposed to Deitas. During the Renaissance period homo humanitas was opposed to the medieval homo barbarus, so studium humanitas is opposed to Gothic scholasticism. «If humanism is understood as the will of man to be free in his own humanity, and therein lies his core value, then the specificity of all humanism is defined by the way in which human nature and freedom are understood. Therefore different ways are found for fulfilling such concepts. The humanitas of all homo humanitas is determined by the already established interpretations of nature and history, of the world and the foundation of the world, i.e. of being as a whole. What is specific to all humanism is the way in which human essence is defined, that is, what turns out to be the humanistic essence of man. But in defining the humanity of man, humanism does not ask about the relation of being to the essence of man» $[17$, p.4]. Roman humanism, as historically the first, emerged from the time when the most universal essence of man is assumed to be most evident. According to this essence, man is animal rationale. This definition is not a mere Latin translation of the Greek zoon, logon, echon, but an assertion of a new interpretation of human nature. This essential definition of 
man is not false, but it does not ask how human essence relates to the truth of being. In relation to human essence we can define ratio eco animal, that is, the reason of a living being, as the capacity to search for principles or categories of being. The question arises about the conditionality of understanding the essence of man, of his definition as a living being among others, but as opposed to plants, animals and God? Thinking of man as a thing existent among other things existent, we are also on the right track. But, speaking of man, we in principle still comprehend him as homo animalis, even when animalis (soul) is conceived as animus sive mens (spirit or mind), and the latter in turn is conceived as subject, personality, class or spirit. Metaphysics thinks of man in the horizon of animalitas, but not in the orientation to his humanitas. It is asserted that man dwells authentically only in his essence and from this essence he derives his foundation. Man's purpose is to comprehend the essence of his being and not merely to explain the nature and history of his actions and deeds. It is clear that the human body is something substantially different from the living organism. Biologism is not overcome if we attribute the soul to the human body, attribute the reason to the soul in order to then loudly sing the praises of the reason. Science studies man as an organism, but it does not mean that in the scientifically explained body seen as an "organic" thing lies the human essence. Such an understanding is not founded. It is by virtue of man's technical dominance that nature reveals its contradictory image to him, thereby concealing its more fundamental essence. We cannot reduce the essence of man only to the being of an animal organism. This is an insufficient definition of human essence, although this deficiency may be overcome by endowing man with either an immortal soul or the power of reason or the quality of personality.

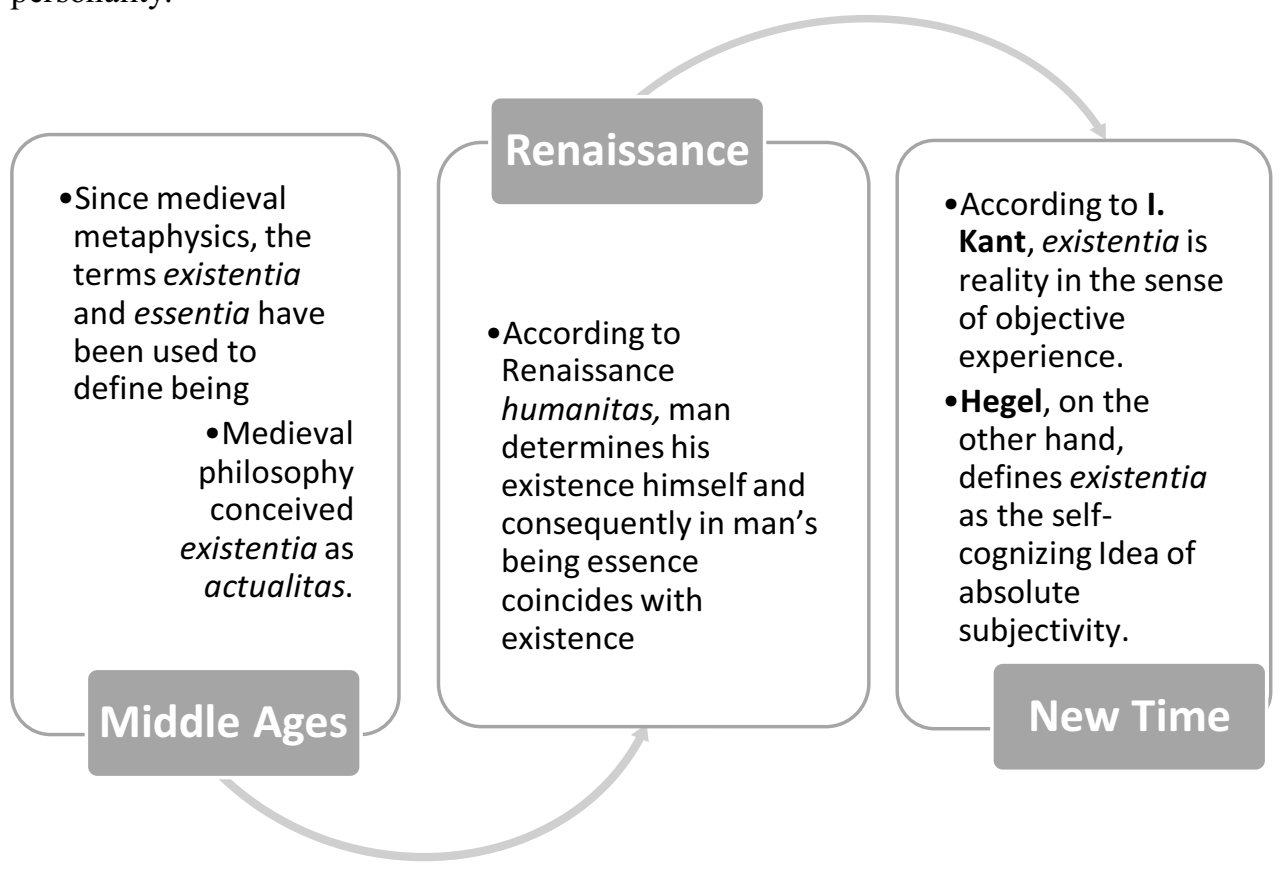

Fig. 4. Essence and existence in the history of philosophical thought.

Since medieval metaphysics, the terms existentia and essentia have been used to define being. And in the divine being, as supreme and primary, essence coincides with existence. According to Renaissance humanitas, man determines his existence himself and consequently in man's being essence coincides with existence. Medieval philosophy conceived existentia as actualitas. According to I. Kant, existentia is reality in the sense of 
objective experience. Hegel, on the other hand, defines existentia as the self-cognizing Idea of absolute subjectivity. As P.S. Gurevich points out, "All these subjects have long been reflected in the works of domestic scholars, carefully registering any mention of selfconsciousness, personality, subjectivity as elements of Hegel's anthropological doctrine" [18, p.73]. And F. Nietzsche comprehends existentia as an eternal return of the same. The origins of this F. Nietzsche's idea are deeply and comprehensively analyzed in the work by V. V. Dudkin [19]. Of all things existent, it is the essence of life phenomenon that is the most difficult to understand. On the one hand, living beings are the most closely connected to us, on the other hand, they are separated by an abyss from our essence. It seems to the religious mind that the essence of the divine is closest to man, whereas in animals many things are quite alien to us. We are more familiar with the essential distance that separates us from the divine than with our terrible, and therefore hardly comprehensible, corporeal kinship with animals. Such reflections cast a strange light on the purpose of man as animal rationale. Plants and animals reside in their respective environments, and they are never placed freely in relation to their being. We cannot say that they have a world of their own, because their surroundings do not need to have a meaningful language. For language, in its essence, has no expression of the needs of living organisms. The essence of language is hardly comprehensible in terms of its symbolic character or even in terms of the function of signifying.

Human existence comprehended in the horizon of ecstasis turns out to be the definition of what man is in his life-defining essence. When we speak of man's being, we are answering the question of human "essence" rather than the question of whether man really is among us or whether he is no longer among us. We are used to asking about what man is or who man is. We speak of the personal comprehension of man or of the knowledge of his objective essence, but both the personal and the objective either omit or falsely interpret the essential unfolding of human existence. The Renaissance idea of humanitas secularized human essence because people saw in it what medieval theology attributed to God: Deus est suum esse (God is his own being). Existence itself is not the fulfillment of essence; it does not fulfill or even does not presuppose that which turns out to be essential. J.P. Sartre expressed the essence of existentialism in the following principle: existence precedes essence. But in this principle the terms existentia and essentia have that metaphysical meaning which since Plato's time has been asserted in the thesis that existentia precedes essentia. And Sartre essentially reverses this thesis. Even if attempts were made in philosophy to define the relation between existentia and essentia in the sense that it appeared in medieval disputes, or in Leibniz's philosophy, or in some other way, it is still necessary to clarify, first of all, from what understanding of being the difference between esse existentiae and esse essentiae is revealed to the thinking. It is important to comprehend, first of all, the relation between man and being, in the context of understanding human essence. The essential experience happens to us when it engenders in us that in which the existing of man himself takes place. In the language of traditional philosophy this sounds like this: the substance of man is his existence. But the term substantia is a translation from Greek, meaning the presence of that which is real in the sense of reality, or else that which is present by itself. When we speak of the substance of man we reveal the way in which man in his own essence becomes present by way of being. Such a definition of man's essence does not at all discard or declare false the interpretation of man as animal rationale, or as a personality, or as spiritual-animated-socialbodily being. Rather, it reveals the fact that the higher determinations of human essence in humanism still fail to fulfill man's own dignity. For it is clear that the essential value of man does not lie in his being as the substance of all things existent, as the subject and administrator of the being of all things existent. The humanitas of man fulfilled in our time deprives man of any essence and he finds himself outside his own place in the universe, that is, as if suspended in a universal vacuum. Believing consciousness is confronted with the destruction 
of everything sacred. The rational is sinking deeper and deeper into the element of the irrational. Physical cognition finds its limit in the principle of indeterminateness. Axiology is sinking ever faster into the subjectivity of moral and aesthetic norms and values. Finally, literally understood sociality is easily interlocked with man's anti-social aspirations, and political thinking turns out to be the most dogmatic in its messianistic claims. Just as man, in his essence, turns out to be constantly outside the present spatial-temporal environment, so he encounters only himself everywhere. In his contemporary essence, man regards the whole world as his own, even if he does not like this world at all. In the state of constant contradiction caused by man's own essence, man's unity with the being of the natural things existent is rejected. The one supports the other. The unity of human essence with the being of all things existent is rejected on the grounds that this essence establishes man in the stage of a substantial subject, that is why the whole environment, including the social context, is assumed to be internally devoid of its own meaning. The unity of the nature of all things existent is decomposed to the opposition, in the language of traditional metaphysics, of the two attributes of being: the being of human essence endowed with the activity of signifying and things existent as an extension stripped of their own even if special meaning. Therefore, the being of all things existent is understood as nothingness (Hegel), which man must fill with his knowledge. But is such a state of things a manifestation of the human essence itself and if so, what is this dominant essence? This is a question that still needs to be comprehended.

\section{Conclusion}

To summarize, it is important to note the following. Man's personality is not defined from the "I", not as subjectivity, but from the facticity of life itself. Life is the way in which being is revealed to the human gaze as all that simply is. In this sense, being is life, where the human is understood as such not because it is grounded in the being of man and is something human, commensurate to man, but because man belongs in the highest degree to this being, to existence, in order to obtain rootedness in being as such. That is, man is called upon to entrust himself to being. In being man finds the basis of his essence. However, only man can be present in this being in such a way that he himself can be in relation to being. For each person being (to be here and now) is first of all "his own". This is why the determination of the "I" personality of an individual person is important. This determination does not only involve the renunciation of one's own egotism, but also requires liberation from all domination, the domination of some existence over him. Presence in being thus requires a determination from each individual person. In this kind of horizon of reflection, it is not the relation of cognition, but the relation of man to the world, understood in the totality of his life-being, that is key. All other definitions are derived from the relation to the human "I". What is meant here is things existent as they exist for me, as they are given to me, as I understand them. Presence in being is determined in its possibilities by the way in which it maintains relation to being. When it comes to understanding being, being must always be understood in relation to human reason; it can never be represented as being by itself. The relationship between being and man manifests itself inevitably in what is called the understanding of being. The question of being one way or another already implies the question of man, since man himself is obviously being. Nowadays, knowledge about man becomes more and more scientific, as the technique of "cultivation" and management of man has moved into something absolute, obligatory, unconditional. In today's information-driven world the question of being is becoming increasingly insignificant. As all things existent have become unconditionally comprehensible, then not only is the question of being considered resolved, but this question is dispensed with as a nonsense. With the prevalence of anthropology the self-deception about the simplest ordering of essential questions increases 
beyond all limits. But in comprehending things existent we call man, it is always necessary to gain an insight into being itself.

Philosophy, then, is such a way of our being, of a finite presence here and now, that moves us towards an awareness of the fundamental problematic nature of our being in the world. The question is how to find ourselves, our place in the world, and, finally, how to find a world in which we could benignly arrange ourselves. In the face of such emptiness in us, the key to this is akin to human acceptance of what we mean by the whole of the world in general. It is in this kind of wholeness, or rather the entirety of the world whole, in which man holds the key positions of recreating and preserving the wholeness of being, that the meaning of man's being-presence in the world is rooted.

\section{References}

1. M.J. Andrés, How Close Are Contemporary Ideas on Human Flourishing and the Classical Philosophy of Man? Personal Flourishing in Organizations, Springer International Publishing 11-35 (2018) DOI: 10.1007/978-3-319-57702-9 2

2. A. Munteanu, I. Costea, R. Palos, A. Jinaru, Entering in the essences of personality studies over archetypes, Procedia - Social and Behavioral Sciences 5, 2272-2276 (2010) https://doi.org/10.1016/j.sbspro.2010.07.448

3. A. Phillips, Rescuing the Human from Human Nature, Critical Quarterly 62(3), 48-52 (2020) DOI: $10.1111 /$ criq.12569

4. Kun Wu, Kaiyan Da, The Impact of Intelligent Society on Human Essence and the New Evolution of Humans, The Fourth International Conference on Philosophy of Information, Berkeley, CA, USA, Proceedings 47(1), $44 \quad$ (2020) https://doi.org/10.3390/proceedings2020047044

5. G.V. Baranov, Being as a problem in philosophy, International Research Journal 7-1 (49), 108-110 (2016) DOI: 10.18454/IRJ.2016.49.145

6. G.V. Baranov, Man as a problem in philosophy, International Research Journal 5-2 (47), 83-85 (2016) DOI: 10.18454/IRJ.2016.47.118

7. M. Gusev, The question of "things existent as things existent" of N. Hartmann and the question of "the meaning of being" of $M$. Heidegger: two views on ontology, HORIZON. Phenomenological research 8 (1), 67-86 (2019) DOI: 10.21638/2226-5260-2019-8-1$\underline{67-86}$

8. N.A. Tereshchenko, T.M. Shatunova, The social as the human, Bulletin of RUDN. Series: Philosophy 21, 4, 505-513 (2017) DOI: 10.22363/2313-2302-2017-21-4-505513

9. A.M. Gaginsky, On the meaning of being and the meanings of things existent: historical and philosophical research, Philosophical Journal 9, 3, 59-76 (2016) DOI 10.21146/2072-0726-2016-9-3-59-76

10. R.A. Burkhanov, O.V. Nikulina, The concept of existentials in M. Heidegger's treatise "being and time", Society: Philosophy, History, Culture 6, 11-15 (2018) DOI: $10.24158 /$ fik.2018.6.1

11. D.A. Fedchuk, The question of time: on the ontological primacy of the present over the past and the future, Bulletin of St. Petersburg State University, Series 17, 3, 73-82 (2016) DOI: 10.21638/11701/spbu17.2016.309

12. S.T. Kruglikov, Time and temporality: Augustine, Kant, Heidegger, Bulletin of PNIPU. Culture. History. Philosophy. Law 1, 24-29 (2017) DOI: 10.15593/perm.kipf/2017.1.03 
13. D.M. Spector, M. Heidegger: the irreversibility of time-being, Humanitarian Vector 12, 3, 75-84 (2017) DOI: 10.21209/1996-7853-2017-12-3-75-84

14. L.N. Boltovskaya, Novalis as a Christian poet and thinker, Christian Reading 2, 152165 (2018) DOI: 10.24411/1814-5574-2018-10039

15. M.G. Kurbanov, On the issue of philosophical understanding of humanity, Bulletin of St. Petersburg State University. Philosophy and Conflictology 34, 1, 37-45 (2018) https://doi.org/10.21638/11701/spbu17.2018.104

16. S.I. Dudnik, Karl Marx and the problem of humanism, Bulletin of St. Petersburg State University. Philosophy and Conflictology 34, 4, 462-473 (2018) https://doi.org/10.21638/spbu17.2018.401

17. T. Torubarova, O. Dyachenko, The problem of personal identity of man in the social and cultural world, E3S Web of Conferences 210, Innovative Technologies in Science and Education (ITSE-2020)16037 (2020) https://doi.org/10.1051/e3sconf/202021016037

18. P.S. Gurevich, The theme of man in the philosophical heritage of Hegel, Philosophical Journal 11, 2, 72-90 (2018) DOI: 10.21146/2072-0726-2018-11-2-72-90

19. V.V. Dudkin, Eternal return - of the same? Scientific Notes of Novgorod State University 8 (33), 11 (2020) DOI: 10.34680/2411-7951.2020.8(33).11 